\title{
Correction: Genome-wide mutational landscape of mucinous carcinomatosis peritonei of appendiceal origin
}

Hakan Alakus ${ }^{1,10}$, Michele L Babicky ${ }^{2}$, Pradipta Ghosh ${ }^{3,5}$, Shawn Yost ${ }^{4}$, Kristen Jepsen $^{1}$, Yang Dai ${ }^{1}$, Angelo Arias ${ }^{1}$, Michael L Samuels ${ }^{9}$, Evangeline S Mose ${ }^{2}$, Richard B Schwab ${ }^{3,5}$, Michael R Peterson ${ }^{6}$, Andrew M Lowy ${ }^{2,5^{*}+}$, Kelly A Frazer ${ }^{1,5,7,8^{*}+}$ and Olivier Harismendy ${ }^{1,5,7^{*}+}$

\section{Correction}

In the originally published version of this article [1], incorrect information about the corresponding authors was given. The following people should have been listed as corresponding authors: Andrew M Lowy, Kelly A Frazer, Olivier Harismendy. The corrected author information is shown above.

\begin{abstract}
Author details
'Division of Genome Information Sciences, Department of Pediatrics and Rady Children's Hospital, University of California San Diego, La Jolla, CA, USA. ${ }^{2}$ Division of Surgical Oncology, Department of Surgery, University of California San Diego, La Jolla, CA, USA. ${ }^{3}$ Department of Medicine, University

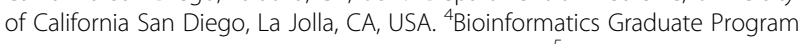
University of California San Diego, La Jolla, CA, USA. ${ }^{5}$ Moores UCSD Cancer Center, University of California San Diego, La Jolla, CA, USA. ${ }^{6}$ Department of Pathology, University of California San Diego, La Jolla, CA, USA. ${ }^{7}$ Clinical and Translational Science Institute, University of California San Diego, La Jolla, CA, USA. Institute for Genomic Medicine, University of California San Diego, La Jolla, CA, USA. ${ }^{9}$ RainDance Technologies, Lexington, MA, USA. ${ }^{10}$ Department of General, Visceral and Cancer Surgery, University of Cologne, Köln, Germany.
\end{abstract}

Received: 30 June 2014 Accepted: 4 July 2014

\section{Reference}

1. Alakus H, Babicky ML, Ghosh P, Yost S, Jepsen K, Dai Y, Arias A, Samuels ML, Mose ES, Schwab RB, Peterson MR, Lowy AM, Frazer KA, Harismendy O: Genome-wide mutational landscape of mucinous carcinomatosis peritonei of appendiceal origin. Genome Med 2014, 6:43.

\section{doi:10.1186/s13073-014-0053-y}

Cite this article as: Alakus et al:: Correction: Genome-wide mutational landscape of mucinous carcinomatosis peritonei of appendiceal origin. Genome Medicine 2014 6:53.

\footnotetext{
*Correspondence: alowy@ucsd.edu; kafrazer@ucsd.edu; oharismendy@ucsd.edu ${ }^{\dagger}$ Equal contributors

${ }^{2}$ Division of Surgical Oncology, Department of Surgery, University of California San Diego, La Jolla, CA, USA

'Division of Genome Information Sciences, Department of Pediatrics and Rady Children's Hospital, University of California San Diego, La Jolla, CA, USA ${ }^{5}$ Moores UCSD Cancer Center, University of California San Diego, La Jolla, CA, USA
}

\section{Submit your next manuscript to BioMed Central and take full advantage of:}

- Convenient online submission

- Thorough peer review

- No space constraints or color figure charges

- Immediate publication on acceptance

- Inclusion in PubMed, CAS, Scopus and Google Scholar

- Research which is freely available for redistribution

Submit your manuscript at

www.biomedcentral.com/submit
() Biomed Central

\section{Biomed Central}

(c) 2014 Alakus et al.; licensee BioMed Central Ltd. This is an Open Access article distributed under the terms of the Creative Commons Attribution License (http://creativecommons.org/licenses/by/4.0), which permits unrestricted use, distribution, and reproduction in any medium, provided the original work is properly credited. The Creative Commons Public Domain Dedication waiver (http://creativecommons.org/publicdomain/zero/1.0/) applies to the data made available in this article, unless otherwise stated. 